\title{
PENGARUH TEKNIK RELAKSASI NAFAS DALAM TERHADAP TINGKAT KECEMASAN PASIEN PRE OPERASI FRAKTUR FEMUR
}

\section{EFFECT OF DEEP BREATHING RELAXATION TECHNIQUE OF ANXIETY LEVEL ON PREOPERATIVE FEMUR FRACTUR PATIENTS}

\author{
Wahyuningsih $^{1^{*}}$, Sutanta $^{2}$, Vina Asna Afifah ${ }^{3}$ \\ ${ }^{* 1}$ Stikes Estu Utomo, Jl. Tentara Pelajar Mudal Boyolali Jawa Tengah, email: wahyubyi28@gmail.com, \\ Indonesia \\ ${ }^{2}$ Stikes Estu Utomo, Jl. Tentara Pelajar Mudal Boyolali Jawa Tengah, email: paksutanta@gmail.com, \\ Indonesia \\ ${ }^{3}$ Stikes Estu Utomo, Jl. Tentara Pelajar Mudal Boyolali Jawa Tengah, email: vina.asna92@gmail.com, \\ Indonesia
}

\begin{abstract}
Background: Fracture is a break of tissue continuity caused by trauma or physical exertion. Surgery or operative action is a management of fracture that can cause anxiety. One of therapy to reduce anxiety can use deep breathing relaxation techniques to reduce tension especially preoperative moment.

Objective: To determine effect of deep breathing relaxation techniques on anxiety level of femur fracture preoperative patient in Karima Utama Surgical Hospital.

Method: The type of research used quantitative research with a Quasi Experiment with Pre Test and Post Test Nonequivalent Control Group design. Sampling technique used Accidental Sampling as many as 30 respondents. Analysis data used Mann-Whitney test with confidence level of $95 \%$.

Result: Obtained $P$-value $=0.000$ means there is a significant effect on the administration of deep breathing relaxation techniques on the anxiety level of femur fracture preoperative patients.

Conclusion: There was a significant effect on the administration of deep breathing

relaxation techniques on the anxiety level of femur fracture preoperative patients in the Karima Utama Surgical Hospital.
\end{abstract}

Keywords: Anxiety, Deep Breathing Relaxation, Fracture

\section{PENDAHULUAN}

Menurut Global Status Report On Road Safety tahun 2015 menyebutkan data di seluruh dunia terdapat lebih dari 1,25 juta korban meninggal akibat kecelakaan lalu lintas dan 50 juta korban luka berat. Menurut data kepolisian Republik Indonesia periode bulan Oktober 2017-Januari 2018 menyatakan jumlah kecelakaan di jalan mencapai 25.391 kasus dengan kematian sebesar 6.253 orang. Menurut Departemen Kesehatan Republik Indonesia tahun 2013 menyebutkan bahwa dari jumlah kecelakaan yang terjadi, terdapat $5,8 \%$ korban cidera atau sekitar delapan juta orang mengalami fraktur pada bagian ekstremitas atas sebesar $36,9 \%$ dan ekstremitas bawah sebesar $65,2 \%$. Kejadian kecelakaan lalu lintas di daerah Jawa Tengah sebanyak 6,2\% mengalami fraktur. ${ }^{1}$ Menurut Desiartama \& Aryana (2017) di Indonesia kasus fraktur Femur merupakan yang paling sering yaitu sebesar 39\% diikuti fraktur humerus (15\%) dan fraktur tibia fibula $(11 \%){ }^{2}$

$$
\text { Penatalaksanaan fraktur adalah }
$$

melakukan imobilisasi di daerah fraktur 
tindakan operasi atau pembedahan yang dapat menimbulkan kecemasan pada pasien. ${ }^{3}$ Kecemasan merupakan reaksi emosional terhadap persepsi adanya bahaya, baik yang nyata maupun yang hanya dibayangkan. Kecemasan dapat berpengaruh terhadap fungsi tubuh yang ditandai dengan adanya peningkatan frekuensi nadi dan respirasi, perubahan tekanan darah dan suhu, relaksasi otot polos pada kandung kemih dan usus, kulit dingin dan lembab, dilatasi pupil dan mulut kering. ${ }^{4}$

Perawat mempunyai kontak yang lama dalam menangani persoalan pasien dan peran perawat dalam upaya penyembuhan pasien menjadi sangat penting. Seorang perawat dituntut bisa mengetauhui kondisi dan kebutuhan pasien, salah satunya dalam perawatan pasien pada saat pre operasi. Perawatan pre operasi dimulai ketika keputusan untuk intervensi bedah dibuat dan berakhir saat pasien dikirim ke meja operasi. Perawatan pre operasi yang efektif dapat mengurangi resiko post operasi, salah satu prioritas keperawatan pada periode ini adalah mengurangi kecemasan pasien. ${ }^{4}$

Fenomena yang ditemukan peneliti dalam studi pendahuluan di Rumah Sakit Karima Utama Surakarta menunjukan bahwa 3 dari 6 pasien fraktur femur yang akan menjalani operasi merasa khawatir dan mengatakan takut akan terjadinya cacat, tidak sembuh, bahkan meninggal. Perawat mempunyai peran penting dalam setiap tindakan baik sebelum operasi sampai setelah operasi. Intervensi dalam mengatasi kecemasan dapat menggunakan teknik nafas dalam, untuk mengurangi ketegangan, menurunkan kecemasan, melepaskan kemarahan, atau mengatasi perasaan yang menyakitkan. Penatalaksanaan keperawatan mandiri yang lebih dipilih peneliti adalah teknik relaksasi nafas dalam untuk mengevaluasi tindakan yang sudah dilaksanakan setiap hari karena kurangnya pemantauan hasil dari tindakan tersebut. Oleh karena itu peneliti tertarik untuk melakukan penelitian tentang pengaruh terapi relaksasi nafas dalam terhadap tingkat kecemasan pada pasien pre operasi fraktur femur di Rumah Sakit Khusus Bedah Karima Utama Surakarta.

\section{METODE PENELITIAN}

Jenis penelitian yang digunakan adalah penelitian kuantitatif dengan rancangan Quasi Ekxperiment dengan Pre Test and Post Test Nonequivalent Control Group. Sampel dalam penelitian ini adalah pasien yang mengalami fraktur femur yang dirawat di ruang rawat inap Rumah Sakit Khusus Bedah Karima Utama Surakarta yang memenuhi kriteria inklusi sebanyak 30 responden yang dibagi menjadi kelompok intervensi dan kelompok control yang dilakukan pada bulan Agustus 2019. Teknik pengambilan sampel menggunakan Accidental Sampling. Analisa data menggunakkan uji Mann-Whitney dengan tingkat kepercayaan 95\%. 


\section{HASIL DAN PEMBAHASAN}

Tabel 1. Karakteristik Responden Berdasarkan Usia, Jenis Kelamin, Pendidikan dan Pekerjaan $(\mathrm{N}=30)$

\begin{tabular}{|c|c|c|c|c|}
\hline \multirow[t]{2}{*}{ Karakteristik } & \multicolumn{2}{|c|}{$\begin{array}{l}\text { Kelompok } \\
\text { Intervensi } \\
(n=15)\end{array}$} & \multicolumn{2}{|c|}{$\begin{array}{l}\text { Kelompok } \\
\text { Kontrol } \\
(n=15)\end{array}$} \\
\hline & $\mathrm{df}$ & $\%$ & $\mathrm{df}$ & $\%$ \\
\hline \multicolumn{5}{|l|}{ Usia } \\
\hline $18-35$ & 3 & 20 & 5 & 33 \\
\hline $36-45$ & 3 & 20 & 3 & 20 \\
\hline $46-55$ & 8 & 53 & 4 & 27 \\
\hline $56-65$ & 1 & 7 & 3 & 20 \\
\hline \multicolumn{5}{|l|}{ Jenis Kelamin } \\
\hline Laki - laki & 5 & 67 & 7 & 47 \\
\hline Perempuan & 10 & 53 & 8 & 53 \\
\hline \multicolumn{4}{|l|}{ Tingkat } & \\
\hline Tidak Sekolah & 1 & 7 & 0 & 0 \\
\hline SD & 5 & 33 & 3 & 20 \\
\hline SMP & 2 & 13 & 1 & 7 \\
\hline SMA & 4 & 27 & 6 & 40 \\
\hline PT & 3 & 20 & 5 & 33 \\
\hline
\end{tabular}

\begin{tabular}{lllll}
\hline Tingkat & & & & \\
Pekerjaan & & & & \\
Tidak bekerja & 0 & 0 & 0 & 0 \\
IRT & 7 & 47 & 2 & 13 \\
Karyawan & 2 & 13 & 3 & 20 \\
Tani & 2 & 13 & 2 & 13 \\
PNS & 0 & 0 & 0 & 0 \\
Wiraswasta & 3 & 20 & 4 & 27 \\
Lainnya & 1 & 7 & 4 & 27 \\
\hline \multicolumn{5}{l}{ Sumber : Data Primer 2019. }
\end{tabular}

Sebagian besar responden yang mengalami fraktur femur pada kelompok kontrol adalah usia 18 - 35 tahun sebanyak 5 responden (33\%). Hal ini didukung data Direktorat Lalu Lintas Kepolisian Daerah Jawa Tengah (2017) usia paling tertinggi yaitu usia 15-24 tahun $(10,6 \%)$ dan usia 25 34 tahun $(41,3 \%)$. Pada kelompok usia muda, mereka lebih banyak melakukan aktivitas yang berat daripada kelompok usia tua. Aktivitas masyarakat usia muda di luar rumah cukup tinggi dengan pergerakan yang cepat dapat meningkatkan resiko terjadinya benturan atau kecelakaan yang menyebabkan fraktur. Kelompok intervensi dengan usia 46 -55 tahun sebanyak 8 responden (53\%). Tulang yang mendapatkan tekanan terus menerus di luar kapasitas dapat mengalami keretakan tulang. ${ }^{5}$ Bagi penderita usia kelompok tua, massa tulang yang rendah cenderung mengalami fraktur karena massa tulang yang rendah tidak mampu menahan daya benturan. Pengurangan massa tulang jelas pada kelompok usia tua, konsumsi kalsium dan vitamin $D$ dapat menguatkan jaringan tulang. Hal ini disebabkan karena kesibukan atau tingkat mobilitas golongan usia tersebut diatas tinggi. Aktivitas pada usia tersebut lebih banyak dan aktivitas di luar rumah cukup tinggi dengan pergerakan yang cepat, dapat meningkatkan resiko terjadinya benturan atau kecelakaan yang menyebabkan fraktur.

Berdasarkan tabel 1 sebagian besar responden pada kelompok intervensi sebanyak 10 responden (53\%) dan kelompok kontrol berjenis kelamin perempuan yaitu sebanyak 8 responden (53\%). Hal ini sejalan dengan penelitian ${ }^{6}$ yang menunjukkan bahwa perempuan lebih banyak dibanding laki-laki yaitu 19 responden $(59 \%)$. Perempuan lebih cemas akan ketidakmampuannya dibandingkan laki-laki karena laki-laki lebih aktif dan eksploratif sedangkan perempuan lebih sensitif. $^{7}$

Hasil penelitian menunjukkan bahwa sebagian besar responden yang mengalami 
fraktur femur pada kelompok kontrol adalah SMA sebanyak 6 responden (33\%) dan kelompok intervensi sebanyak 5 responden (33\%) mempunyai tingkat pendidikan SD. Tingkat pendidikan rendah mempengaruhi tingkat pengetahuan responden dalam menerima informasi, dalam hal ini dapat meningkatkan kecemasan. Hal ini sesuai dengan penelitian ${ }^{8}$ sebagian besar status pendidikan responden yang mengalami kecemasan pada fraktur adalah pada tingkat status pendidikan SMA. Kejadian fraktur bisa terjadi pada individu dengan tingkat pendidikan tinggi maupun rendah. Latar belakang pendidikan merupakan faktor yang mempengaruhi pola pikir seseorang, pendidikan membetuk cara berpikir seseorang termasuk membentuk kemampuan untuk memahami faktor-faktor yang berkaitan dengan penyakit dan menggunakan pengetahuan tersebut untuk menjaga kesehatan. ${ }^{3}$ Pendidikan yang tinggi memudahkan seseorang untuk menerima pengetahuan untuk upaya mengatasi masalah atau persiapan yang dilakukan sebelum operasi.

Hasil penelitian menunjukkan bahwa sebagian besar responden yang mengalami fraktur femur pada kelompok intervensi yaitu Ibu Rumah Tangga sebanyak 7 responden (47\%) dan pada kelompok kontrol bekerja sebagai wiraswasta sebanyak 4 responden (27\%). Penyebab dari fraktur adalah kecelakaan lalu lintas, hal ini karena meningkatnya jumlah kendaraan dan kurang tertibnya pengguna lalu lintas. Hal ini disebabkan karena kesibukan atau tingkat mobilitas golongan usia tersebut diatas tinggi. Aktivitas pada usia tersebut lebih banyak dan aktivitas di luar rumah cukup tinggi dengan pergerakan yang cepat, dapat meningkatkan resiko terjadinya benturan atau kecelakaan yang menyebabkan fraktur, penyebab paling banyak yaitu berolahaga, kecelakaan lalu lintas, jatuh dari ketinggian maupaun karena lingkungan.

Tabel 2. Tingkat kecemasan pada kelompok intervensi dan kelompok control

\begin{tabular}{|c|c|c|c|c|c|c|c|c|}
\hline \multirow{3}{*}{$\begin{array}{l}\text { Tingkat } \\
\text { Kecemasan }\end{array}$} & \multicolumn{4}{|c|}{$\begin{array}{c}\text { Kelompok } \\
\text { Intervensi } \\
(n=15)\end{array}$} & \multicolumn{4}{|c|}{$\begin{array}{l}\text { Kelompok Kontrol } \\
\qquad(n=15)\end{array}$} \\
\hline & \multicolumn{2}{|c|}{ Pre } & \multicolumn{2}{|c|}{ Post } & \multicolumn{2}{|l|}{ pre } & \multicolumn{2}{|c|}{ post } \\
\hline & $\mathrm{df}$ & $\%$ & $d f$ & $\%$ & $\mathrm{df}$ & $\%$ & $\mathrm{df}$ & $\%$ \\
\hline $\begin{array}{l}\text { Tidak } \\
\text { cemas }\end{array}$ & 0 & 0 & 3 & 20 & 0 & 0 & 0 & 0 \\
\hline Ringan & 0 & 0 & 8 & 53 & 0 & 0 & 1 & 7 \\
\hline Sedang & 9 & 60 & 4 & 27 & 5 & 33 & 6 & 40 \\
\hline Berat & 6 & 40 & 0 & 0 & 10 & 67 & 8 & 53 \\
\hline Asymp. Sig & & & & & & & & \\
\hline
\end{tabular}

Hasil penelitian pada tabel diatas menunjukkan bahwa tingkat kecemasan responden kelompok kontrol sebagian besar berada pada tingkat kecemasan "berat" baik saat pretest atau posttest dengan Asymp. Sign/p value 0.083 artinya tidak ada perbedaan sebelum dan sesudah, sedangkan kelompok intervensi mengalami penurunan dari kecemasan sedang $(60 \%)$ menjadi kecemasan ringan $(53 \%)$ dengan $p$ value 0.000 artinya terdapat perbedaan sebelum dan sesudah dilakukan intervensi. Hal ini sesuai penelitian ${ }^{9}$ yang berjudul Relaksasi Nafas Dalam menurunkan Kecemasan 
Pasien Pre Operasi Bedah Abdomen. Kecemasan merupakan reaksi emosional terhadap persepsi adanya bahaya, baik yang nyata maupun yang hanya dibayangkan. Keadaan emosional pasien dalam hal ini cemas, akan berpengaruh kepada fungsi tubuh menjelang operasi. Kecemasan yang tinggi, dapat mempengaruhi fungsi fisiologis tubuh yang ditandai dengan adanya peningkatan frekuensi nadi dan respirasi, pergeseran tekanan darah dan suhu, relaksasi otot polos pada kandung kemih dan usus, kulit dingin dan lembab, peningkatan respirasi, dilatasi pupil, dan mulut kering. ${ }^{4}$

Hasil penelitian di ruang rawat inap RS Karima Utama Surakarta didapatkan tingkat kecemasan responden setelah diberikan teknik relaksasi nafas dalam yaitu sebagian responden tingkat kecemasan ringan. Kecemasan ringan berhubungan dengan ketegangan kehidupan sehari-hari. Ketegangan tersebut akan menyebabkan seseorang menjadi waspada dan meningkatkan lahan persepsinya. ${ }^{10}$

Tabel 3. Perbedaan kecemasan post test kelompok intervesi dan kelompok kontrol Hasil post-test kelompok kontrol \& intervensi

\begin{tabular}{ll}
\hline $\mathrm{Z}$ & -4.007
\end{tabular}

Asymp. Sig. $\quad 0.000$ (2-tailed) Sumber : Data Primer 2019.

Berdasarkan Uji Mann - Whitney test digunakan untuk mengetahui perbedaan pengaruh antara hasil Pre test dan Post test. Pada masing - masing variabel. Jika nilai sig. 2 tailed / nilai $p$ value $<0.05$ artinya terdapat perbedaan yang signifikan antara
Pre Test dan Post Test. Hasil dari penelitian ini $p$ value 0.000 artinya teknik nafas dalam ada pengaruh terhadap tingkat kecemasan pre operasi fraktur Femur di Rumah Sakit Khusus Bedah Karima Utama.

Mekanisme relaksasi nafas dalam (deep breathing) pada system pernafasan berupa suatu keadaan inspirasi dan ekspirasi pernafasan dengan frekuensi pernafasan menjadi 6 - 10 kali permenit sehingga terjadi peningkatan regangan kardiopulmonari. Stimulasi peregangan di arkus aorta dan sins karoris diterima dan diteruskan oleh syaraf vagus ke medulla oblongata (pusat regulasi kardiovaskuler), selanjutnya merespon terjadinya peningkatan reflex baroreseptor. ${ }^{11}$

Respon tahap awal tubuh HPA (Hipotalamus-Pituitary-Adrenal) memegang peranan penting dalam beradaptasi terhadap stress eksternal maupun internal dan pada keadaan depresi terjadi peningkatan aktivitas HPA yang ditandai dengan pelepasan $\mathrm{CRH}$ (Corticotropin-Releasing-Hormone) dari hipotalamus. ${ }^{12} \mathrm{CRH}$ banyak ditemukan di PVN (Paraventricular-Nucleus) hipotalamus. Kemudian pelepasan $\mathrm{CRH}$ dari hipotalamus dirangsang noradrogenik, serotonergik dan kalinergik yang menyebabkan terjadinya depresi/ cemas. Peningkatan rangsangan terhadap hipofesis anterior menyebabkan sekresi ACTH (Adreno Cortico Tropin Hormone). ACTH berperan merangsang keluarnya kortisol dari korteks adrenal. Kemudian peningkatan ACTH pada keadaan cemas bila berlangsung lama dapat 
menimbulkan hiperaktifitas kelenjar adrenal dan kortisol setelah itu, yang dikeluarkan dari kelenjar adrenal lalu masuk dalam sirkulasi umum, dimana pada pasien cemas terjadi peningkatan kadar kortisol terutama pada sore atau malam hari. Sehingga penting untuk mempertahankan kondisi mental dan fisik seseorang.

\section{KESIMPULAN}

Berdasarkan penelitian mengenai Pengaruh teknik relaksasi nafas dalam terhadap tingkat kecemasan pasien pre operasi Fraktur Femur di RS Khusus Bedah Karima Utama Surakarta dapat disimpulkan yaitu: Usia Kelompok intervensi rentang usia 46 - 55 tahun \& kelompok kontrol usia 18 35 tahun, jenis kelamin kelompok intervensi dan kontrol jenis kelamin perempuan, tingkat pendidikan kelompok intervensi adalah SD dan kelompok kontrol tingkat adalah SMA, pekerjaan kelompok intervensi adalah Ibu Rumah Tangga dan kelompok kontrol wiraswasta. Responden yang mengalami kecemasan pada kelompok kontrol adalah kecemasan berat, sedangkan kelompok intervensi adalah kecemasan ringan. Terdapat perbedaan yang signifikan pada kelompok intervensi dan kelompok kontrol.

Saran untuk peneliti selanjutnya bisa menggunakan intervensi yang sama namun menggunakan metode dan pasien yang berbeda. Bagi Institusi pendidikan hasil ini dapat dijadikan sebagai bahan masukan dalam proses pembelajaran khususnya penanganan non farmakologi menggunakan teknik relaksasi dalam untuk menurunkan kecemasan.

\section{TERIMA KASIH}

1. Nining Tri Maryani, dr, Direktur RSKB Karima Utama Surakarta, email: rskarimautama.solo@gmail.com

2. Seluruh responden dan perawat di ruang rawat inap dan ruang operasi RSKB Karima Utama Surakarta

\section{KEPUSTAKAAN}

1. Riset Kesehatan Dasar. Riset kesehatan dasar 2013 provinsi Jawa Tengah. Jakarta : Kemenkes RI

2. Desiartama, A. Aryana, I.G.N.W. Gambaran karakteristik pasien fraktur femur akibat kecelakaan lalu lintas pada orang dewasa di RSUP Sanglah Denpasar Tahun 2013. E-Jurnal Medika. Mei 2017; Volume 4, (5), Hal. 1-4

3. Potter, P.A., Perry, A.G., Stockert, P.A., Hall, A.M. Fundamental of nursing. Edisi 8. St. Louis Missouri: Elsevier Mosby; 2013.

4. Smeltzer, C.S. Bare. B.G. Buku ajar keperawatan medikal bedah volume 1 Brunner \& Suddart. Edisi 8. Jakarta : EGC; 2009.

5. Sjamsuhidajat, R. Jong, W.D. Buku ajar ilmu bedah. Edisi 3. Jakarta : EGC; 2011.

6. Widyastuti, Y. Gambaran kecemasan pada pasien pre operasi faktur femur di RS Ortopedi Prof Dr.R. Soeharso Surakarta. Profesi (Profesional Islam) : Media Publikasi Penelitian. Maret 2015; Volume 12, (2), Hal. 31-36

7. Mubarak, I. Indrawati, L. Susanto, J. Buku 1 ajar ilmu keperawatan dasar. Jakarta : Salemba Medika; 2015.

8. Permana, O. Nurchayati, S. Herlina. Pengaruh range of motion (ROM) terhadap intensitas nyeri pada pasien post operasi fraktur ekstremitas 
bawah. Jurnal Online Mahasiswa

Program Studi IImu Keperawatan

Universitas Riau. Oktober 2015; Volume

2, (2), Hal. 1327-1334

9. Rokawie, A.C.N. Sulastri. Anita. Relaksasi nafas dalam menurunkan kecemasan pasien pre operasi bedah abdomen. Jurnal Kesehatan Politeknik Kesehatan Kementrian Kesehatan Tanjung Karang. Agustus 2017; Volume 8, (2), Hal. 257-262

10. Manurung, N. Keperawatan medikal bedah jilid 3 konsep mind mapping dan NANDA NIC NOC. Jakarta: Trans Info Media; 2018.

11. Muttaqin, A. Buku ajar asuhan keperawatan klien ganguan Sistem muskuluskeletal. Jakarta : EGC; 2008.

12. Amir, N. Depresi: aspek neurobiologi, diagnosis dan tatalaksana. Jakarta: Balai penerbit FK UI; 2005. 